\title{
The influence of habitat structure on fish assemblages in Amazonian streams of Machado river basin
}

\author{
Igor D. da Costa $^{1} \&$ Vanessa M. da Rocha ${ }^{2}$
}

1. Laboratório de Ciências Ambientais, Departamento de Engenharia de Pesca, Universidade Federal de Rondônia UNIR. Rua da Paz, Lino Alves Teixeira, CEP 76196-000, Presidente Médici, RO, Brasil; igordavid@unir.br

2. Laboratório de Biologia e Cultivo de Peixes de Água Doce (LAPAD), Departamento de Aquicultura - Centro de Ciências Agrárias (CCA), Universidade Federal de Santa Catarina - UFSC. Rodovia Francisco Thomaz Dos Santos, 3532 - Armação do Pântano Do Sul Florianópolis SC CEP 88066-260; vanessa.engenhariapesca@gmail.com

\author{
Received 27-XI-2015. Corrected 14-VII-2016. Accepted 17-VIII-2016.
}

\begin{abstract}
Igarapés are Amazonian streams that are extremely susceptible to environmental changes. Due to the rapidly occurring riparian land use changes, and the several impacts these may have on fish assemblages, it is highly valuable to describe and understand the current relationships between these assemblages and the local environmental conditions, especially in barely know areas. In this research, we studied the taxonomic composition and fish assemblage attributes variation in three streams with different riparian conservation conditions: forest, intermediate and pasture. Samplings were performed every two months from October 2011 to September 2012, in three $1^{\text {st }}$ order streams in the Machado River Basin, Rondônia. Fish were collected using trawls (seine net with a mesh size of $2 \mathrm{~mm}$ ) and dip nets $(2 \mathrm{~mm}$ mesh) along the entire stretch; the obtained samples were preserved and identified per site type. A total of 2141 fish specimens belonging to 59 species, 17 families and five orders were recorded. Unlike the intermediate and pasture streams, the forest stream showed a high richness and low abundance. The forested stream exhibited the highest diversity and evenness value, and had low dominance, unlike the other streams. The variance partitioning and partial Redundancy Analysis (pRDA) indicated that assemblage composition was significantly explained by the environmental variables such as: depth, water velocity, pteridophytes and grasses, but not by spatial predictors. The non-metric multidimensional scaling (NMDS) analysis showed that intermediate and pasture streams separated from the forested stream. We concluded that both, the stream environmental variables and fish assemblage attributes were influenced by the different conservation status and land cover. Given the influence of regional processes, which have a pervasive role in local fish assemblages, land use at the watershed scale is important, especially to explain the higher richness and diversity found in forested streams. Rev. Biol. Trop. 65 (1): 103-115. Epub 2017 March 01.
\end{abstract}

Key words: complexity, conservation, richness, fish assemblages.

Tropical rainforest streams are nutrientpoor streams with a dense forest cover that prevents light from reaching the water surface (Walker, 1995). Their biological and physicochemical features are therefore greatly influenced by the surrounding vegetation (Mendonça, Magnusson, \& Zuanon, 2005). They are also considered to be extremely vulnerable to environmental impacts, such as land-use change by agricultural purposes, which may cause environmental degradation
(Dembkowski \& Miranda, 2012) and influence aquatic vertebrate fauna (Miserendino et al., 2011).

Physicochemical habitat characteristics are considered to be highly relevant factors affecting the distribution of species and the organization of communities in streams (Hoeinghaus, Winemiller, \& Birnbaum, 2007). Variations in species composition, structure and distribution in fish assemblages has been attributed to area (i.e. basin area, lake surface area), regional 
net primary production, habitat heterogeneity (Tedesco, Oberdorff, Lasso, Zapata, \& Hugueny, 2005), substrate type, microhabitat type and water flow (Mendonça et al., 2005).

Land use plays a key role in shaping the environment on global, regional and local scales (Krusche et al., 2005). Changes in the type of land cover influence the biodiversity and ecosystem services (Foley et al., 2007), global climate (Hartmann et al., 2013), biogeochemical cycles and water cycles (Laudon et al., 2016). The removal of native forest at the watershed or at the riparian buffer scale, affects stream characteristics at the local scale (Cruz, Miranda, \& Cetra, 2013), such as flow, depth, substrate composition, litter amount, stability of stream banks, and structural complexity (Lorion \& Kennedy, 2009; Casatti, Ferreira, \& Carvalho, 2009).

Several studies have shown relationships between ichthyofauna and land use in microbasins in temperate regions (Roth, Allan, \& Ericson, 1996; Fitzgerald, Kott, Lanno, \& Dixon, 1998; Rosenvald, Järvekülg, \& Lõhmus, 2014). However, in the Neotropics, this issue is not well explored (Levêque, Oberdorff, Paugy, Stiassny, \& Tedesco, 2008) and is a critical situation, considering that $40 \%$ of the Neotropical ichthyofauna remains unknown (Reis, Kullander, \& Ferraris, 2003). In addition to a better knowledge of the taxonomy of the ichthyofauna, an understanding of the quantitative structure of the ichthyofauna and its relationship with the environment is also important to support environmental conservation and recovery strategies (Barletta et al., 2010).

In the Brazilian Amazon, one of the major causes of deforestation is the logging and burning of tropical forest, to produce pastures for livestock. This mechanism initially enriches the soil surface with cations from the burned plant biomass, which is transferred to the soil in the form of ashes (Ferreira, Cyrino, DuarteNeto, \& Martinelli, 2012). This process is commonly observed in the Machado River basin where land use resulted in extensive cattle farming, which is one of the main economic activities in the Rondônia state (Costa, 2014).
The present study aimed to determine the ichthyofauna composition in three streams with different land cover (forest, mix of forest and pasture, and pasture) in the central region of the Machado River basin in the state of Rondônia (Brazil) and to investigate the relationships between fish species and the environmental variables. We hypothesized that streams in pasture areas would exhibit altered habitat conditions and diversity lower fish assemblages compared with sites with preserved and intermediate degrees of preservation of land cover, and that these would support more balanced and diverse assemblages.

\section{MATERIALS AND METHODS}

Study area: This study was conducted in the Machado River basin, which drains the most populated area of Rondônia, Northern Brazil, with a total catchment area of $75400 \mathrm{~km}^{2}$. It rises in the Pimenta Bueno River and flows into Madeira River, in the North of the state of Rondônia (Fernandes \& Guimarães, 2002). The climate is characterized by temperatures ranging from 19 to $33{ }^{\circ} \mathrm{C}$, and the annual rainfall is approximately $2500 \mathrm{~mm}$ (Krusche et al., 2005). There are two well-defined seasons: the dry season (from late May to September) and the rainy season (from October to April) (Fernandes \& Guimarães, 2002). Sampling was performed every two months from October 2011 to September 2012 in three $1^{\text {st }}$ order streams with different levels of conservation, being a forested stream (FO) (Minuano stream; $\left.11^{\circ} 01^{\prime} \mathrm{S}-61^{\circ} 54^{\prime} 42^{\prime \prime} \mathrm{W}\right)$, a stream with intermediate (IN) degrees of conservation (Cris stream; $11^{\circ} 15^{\prime} \mathrm{S}-61^{\circ} 51^{\prime} 24^{\prime}$ ' W, ) and a stream located in pasture (PA) (Vinte e três stream; $11^{\circ} 05^{\prime} \mathrm{S}-61^{\circ} 53^{\prime} 29^{\prime}$ ' W), all located in the Machado River Basin, Rondônia. The study sites, located in private areas, showed total absence of domestic/industrial effluents, aquaculture, agriculture and dams, and the area were formerly used for cattle farming but currently such activity was absent. 
Environmental data: The average width (m) of each stream was based on measurements at six equidistant points along a $50 \mathrm{~m}$ stretch. The average depth $(\mathrm{m})$ was calculated from random surveys along the same stretch. The water velocity $(\mathrm{m} / \mathrm{s})$ was determined by measuring the time a floating object traveled a known distance $(1 \mathrm{~m})$ in the center of the channel (Casatti, Langeani, \& Castro, 2001). The average transect area (At) was calculated as the average of the areas of six transects in each section studied using the following formula: $A t=\left[\left(Z_{1}+Z_{2}\right) / 2\right] . L+\left[\left(Z_{2}+Z_{3}\right) / 2\right] . L$ $+\ldots+\left[\left(Z_{n}+Z_{n+1}\right) / 2\right] . L$, where $Z$ is the depth measured in each segment and $L$ is the width of each segment. The mean flow $\left(\mathrm{m}^{3} / \mathrm{s}\right)$ was calculated from the average water velocity and the width and depth of the channel using the following formula: $\mathrm{Q}=\mathrm{At} * \mathrm{Vm}$, where $\mathrm{Q}=$ flow, $\mathrm{Vm}=$ mean water velocity, and $\mathrm{At}=$ average transect area.

The physical structure of each stream was evaluated in two dimensions (at the land-water transition zones and on the substrate types), for this purpose, each sampled section was divided into five smaller sections measuring $10 \mathrm{~m}$ each. To determine the physical structure of the land-water ecotone and the substrate types, the proportions of the elements making up these zones were measured at each section (total $100 \%$ ), a visual-based habitat approach was based on previous protocols (Gorman \& Karr, 1978; Barbour, Gerritsen, Snyder, \& Stribling, 1999). The physical structure of the substrate was determined from the visual estimated proportion of sand (minimum diameter from 0.05 $\mathrm{mm}$ to $2 \mathrm{~mm}$ ), clay, trunks (wood larger than $10 \mathrm{~cm}$ in diameter), coarse litter (composed of leaves and small branches), fine litter (fine particulate matter), roots (tangled roots of riparian vegetation) and macrophytes (aquatic vegetation), which were evaluated by visual estimation. The land-water ecotone (lateral distance of $10 \mathrm{~m}$ started at the adjacent portion of the stream) structures, on the left and right banks, were analyzed for the occurrence of five habitat descriptors: pteridophytes, fine roots intertwined of riparian vegetation, grasses, woody angiosperms and bare bank.

Fish sampling: Fish were collected for one hour during the daytime (11:00-12:00) in a $50 \mathrm{~m}$ stretch. Three collectors used hand gathering techniques with trawls (seine net with a mesh size of $2 \mathrm{~mm}$ ) and dip nets ( $2 \mathrm{~mm}$ mesh) along the entire stretch, selecting the best technique for each mesohabitat and microhabitat. Before the collections, the ends of the sampling sections were blocked with fine-mesh nets ( $5 \mathrm{~mm}$ between opposite knots) to prevent the fish escaping, regardless of the collection method used.

The collected fish were fixed in $10 \%$ formalin, placed in plastic bags, counted and identified and later transferred to $70 \%$ alcohol. Taxonomic identification of the species was performed using specialized literature (e.g., Casatti, Pérez-Mayorga, Carvalho, Brejão, \& Costa, 2013; Queiroz et al., 2013) and with the assistance of experts from several institutions. Voucher specimens were deposited in the fish collection at the Universidade Federal de Rondônia, Porto Velho, Rondônia state, Brazil (Vouchers: UFRO-ICT 023980 to UFRO-ICT 024000).

The Shapiro-Wilk normality test and Levene's test for homoscedasticity were applied to the data, to determine whether the assumptions of the parametric and nonparametric analyses for the environmental variables, abundance, species richness, diversity and evenness were satisfied. To compare these data within and between wet and dry periods, the KruskalWallis test was used when the assumptions of normality and homoscedasticity were not met, even after transformation (log-transformed) of the data. When the data were normally distributed, an analysis of variance (ANOVA) was performed. Both of the analyses were performed with Statistica 7.1.

The Shannon-Wiener diversity index $(\mathrm{H})$, Berger-Parker dominance index (D) and Pielou's evenness index (e) (Ludwig \& Reynolds, 1988) were calculated for each site and season, and the species richness was estimated 
using the bootstrap method (1 000 randomizations). This is an incidence-based estimator of the species richness of rare species (collected only once or twice in samplings) that is used to estimate the total species richness and pattern deviation (Colwell, 2013).

Non-metric multidimensional scaling (NMDS) analysis based on species abundance was conducted to characterize the composition of fish assemblages. The dissimilarity matrix used in the ordination was constructed using the Bray-Curtis index. For the NMDS analysis the data were previously log-transformed $(\log x+1)$. The NMDS calculates distortion, or stress, between the similarity matrix and the ordination produced in the graphical representation of the axes. In this study, the stress values were below 0.1 , which corresponded to a good ordering, ensuring good reliability in the interpretation of the results (Clarke \& Warwick, 1994).

To represent the spatial variation a Principal Coordinates of Neighbor Matrices (PCNM) was performed (Dray, Legendre, \& Peres-Neto, 2006). To perform the PCNM analysis, watercourse distances among sampling points were measured through Google Earth, using drainage net with 150 ha (Google Earth, 2016), resulting in a triangular matrix of distances. Then, a matrix of truncated distance was calculated to retain the distance neighbors sampling points. A Principal Coordinate Analysis (PCoA) of the truncated matrix was computed, and its positive eigenvectors were retained (Borcard, Gillet, \& Legendre, 2011) to be used as spatial predictors (Dray et al., 2006). A Partial Redundancy Analysis (pRDA) with a Variation Partitioning method (Borcard \& Legendre, 2002) was used to quantify the relative importance of environmental variables and spatial distances (positive PCNM eigenvectors) in explaining the variation in species composition.

The pRDA is similar to multiple regressions, except that it allows for the analysis of multiple response variables. To remove collinearity among variables, a forward selection $(\alpha=$ 0.05 ) procedure was applied in pRDA to select and evaluate sets of environmental variables that each explained significant additional variation in stream assemblage composition and abundance (Ter Braak \& Smilauer, 1998). Significance of canonical axes and variation explained by environmental variables were based on 10000 Monte Carlo permutations. The RDA decomposes the total explained variation into environmental and spatial components. Then, the unbiased Variation Partitioning method proposed by Peres-Neto, Legendre, Dray and Borcard (2006) was used to obtain the variance explained exclusively by environmental and spatial components, and their respective adjusted coefficients of determination $\left(R_{a d j}{ }^{2}\right)$. The NMDS and pRDA analyses were performed only with species greater abundance than five individuals.

The VEGAN and PCNM packages were used to run pRDA and PCNM analyses, which were performed with $\mathrm{R}$ software (R Development Core Team, 2009). The NMDS analysis was performed with PAST version 2.17 (Hammer, Harper, \& Ryan, 2001), which was also used to determine the diversity index and richness estimates. The results were considered significant when $\mathrm{P} \leq 0.05$.

\section{RESULTS}

The intermediate and pasture streams were surrounded by abandoned pastures, while the forested stream was surrounded by primary forest. There were no macrophytes in the forested and intermediate stream, but the pasture stream showed a large number of emergent rooted macrophytes. Both banks of the forested stream were composed of shrubby and woody angiosperms. The right bank of the intermediate stream was predominantly composed of grasses and the left bank was composed of woody angiosperms. The banks of the pasture were composed of narrow stretches of woody angiosperms with stretches of bare bank (Table 1).

The results of the Kruskal-Wallis test indicated that the forested stream presented a higher percentage of pteridophytes $(H=16.2$, $\mathrm{P}<0.05)$, fine root intertwined $(\mathrm{H}=16.2, \mathrm{P}<$ $0.05)$, woody angiosperms $(\mathrm{H}=15.7, \mathrm{P}<0.05)$, 
TABLE 1

Environmental descriptors of the forested (FO), intermediate (IN) and pasture (PA) streams in the Machado River basin, RO

\begin{tabular}{|c|c|c|c|}
\hline Descriptors & FO & IN & $\mathrm{PA}$ \\
\hline Land use in the adjacent matrix & Primary forest & Pasture & Pasture \\
\hline Presence of macrophytes & Absent & Absent & Present \\
\hline $\begin{array}{l}\text { Riparian ecotone vegetation } \\
\text { on the right bank }\end{array}$ & $\begin{array}{l}\text { Shrubby and woody } \\
\text { angiosperms }\end{array}$ & Grasses & $\begin{array}{c}\text { Narrow stretches of woody angiosperms } \\
\text { with stretches of bare bank. }\end{array}$ \\
\hline $\begin{array}{l}\text { Riparian ecotone vegetation } \\
\text { on the left bank }\end{array}$ & $\begin{array}{l}\text { Shrubby and woody } \\
\text { angiosperms }\end{array}$ & $\begin{array}{l}\text { Woody } \\
\text { angiosperms }\end{array}$ & $\begin{array}{c}\text { Narrow stretches of woody angiosperms } \\
\text { with stretches of bare bank. }\end{array}$ \\
\hline \multicolumn{4}{|l|}{ Physical variables } \\
\hline Depth (m) & $42.3 \pm 21.8$ & $26.0 \pm 5.4$ & $24.3 \pm 6.4$ \\
\hline Width (m) & $1.9 \pm 0.4$ & $2.0 \pm 0.7$ & $2.1 \pm 0.6$ \\
\hline Water velocity $(\mathrm{m} / \mathrm{s})^{*}$ & $0.3 \pm 0.1^{\mathrm{a}}$ & $0.2 \pm 0.1^{\mathrm{a}}$ & $0.1 \pm 0.0^{\mathrm{b}}$ \\
\hline Flow $\left(\mathrm{m}^{3} / \mathrm{s}\right)$ & $29.1 \pm 21.0$ & $15.4 \pm 7.0$ & $11.2 \pm 6.8$ \\
\hline \multicolumn{4}{|l|}{ Ecotone characteristics } \\
\hline Pteridophytes $(\%)^{* *}$ & $5.0 \pm 0.8^{\mathrm{a}}$ & $0.0^{\mathrm{b}}$ & $0.0^{\mathrm{b}}$ \\
\hline Fine roots intertwined $(\%)^{* *}$ & $4.8 \pm 0.7^{\mathrm{a}}$ & $0.0^{\mathrm{b}}$ & $0.0^{\mathrm{b}}$ \\
\hline Grasses $(\%)^{* *}$ & $0.0^{\mathrm{a}}$ & $23.4 \pm 1.3^{b}$ & $42.8 \pm 2.6^{\mathrm{c}}$ \\
\hline Woody angiosperms $(\%)^{* *}$ & $65.6 \pm 1.7^{\mathrm{a}}$ & $43.0 \pm 2.3^{b}$ & $10.0 \pm 1.3^{\mathrm{c}}$ \\
\hline Bare bank $(\%)^{* *}$ & $0.0^{\mathrm{b}}$ & $0.0^{\mathrm{b}}$ & $42.2 \pm 2.0^{\mathrm{a}}$ \\
\hline \multicolumn{4}{|l|}{ Substrate categories } \\
\hline Rock $(\%)^{* *}$ & $4.6 \pm 0.8^{\mathrm{a}}$ & $0.0^{\mathrm{b}}$ & $19.8 \pm 3.5^{c}$ \\
\hline Sand $(\%)^{* *}$ & $59.5 \pm 8.0^{\mathrm{b}}$ & $89.1 \pm 3.3^{\mathrm{a}}$ & $80 . \pm 3.5^{\mathrm{a}}$ \\
\hline Fine litter $(\%)^{* *}$ & $11.3 \pm 1.9^{\mathrm{a}}$ & $6.3 \pm 1.0^{\mathrm{b}}$ & $0.0^{\mathrm{c}}$ \\
\hline Coarse litter $(\%)^{* *}$ & $16.7 \pm 2.2^{\mathrm{a}}$ & $0.0^{\mathrm{b}}$ & $0.0^{\mathrm{b}}$ \\
\hline Large branches and trunks $(\%)^{* *}$ & $10.8 \pm 1.3^{\mathrm{a}}$ & $4.5 \pm 2.9^{b}$ & $0.0^{\mathrm{c}}$ \\
\hline
\end{tabular}

$*=$ mean \pm standard deviation and $\mathrm{P}<0.05$, and $* *=$ median \pm standard deviation and $\mathrm{P}<0.05$. Different letters indicate the significant differences between pairs of means in the ANOVA and Kruskal-Wallis tests.

rock-type substrate $(\mathrm{H}=16.0, \mathrm{P}<0.05)$, fine litter $(\mathrm{H}=15.9, \mathrm{P}<0.05)$, coarse litter $(\mathrm{H}=$ $16.1, \mathrm{P}<0.05)$ and large branches and trunks $(\mathrm{H}=15.9, \mathrm{p}<0.05)$ than the other analyzed streams. The pasture stream had the highest percentage of grasses $(\mathrm{H}=15.7, \mathrm{P}<0.05)$ and bare bank $(\mathrm{H}=16.1, \mathrm{P}<0.05)$ on the land-water ecotone. The forested and intermediate streams had higher water velocities (ANOVA, $\mathrm{F}=3.85$, $\mathrm{p}<0.05)$ than the pasture stream, whereas the intermediate and pasture stream had higher percentages of sand (Kruskal-Wallis, $\mathrm{H}=14.6, \mathrm{P}<$ $0.05)$ than the forested stream (Table 1).

A total of 2141 specimens belonging to 59 species, 17 families and 5 orders were recorded. The intermediate $(\mathrm{n}=544)$ and pasture $(\mathrm{n}=1119)$ streams had higher abundances (Kruskal-Wallis, $\mathrm{H}=11,5 ; \mathrm{P}<0.05$ ) than the forested $(\mathrm{n}=476)$ (Appendice 1). The forested stream had higher richness $(\mathrm{S}=41)$ (ANOVA, $\mathrm{F}=15.0, \mathrm{p}<0.05)$ than the intermediate and pasture streams, which had 27 and 25 species, respectively. The estimated richness generated by the bootstrap method was 47 species in the forested and 31 in both the intermediate and pasture stream. Forested stream exhibited the highest diversity $\left(\mathrm{H}^{\prime}=1.10\right)$ and evenness $(\mathrm{e}$ $=0.21)$ value, and had a low dominance $(\mathrm{D}=$ $0.31)$, unlike with intermediate $\left(H^{\prime}=0.81 ; \mathrm{D}=\right.$ $0.54 ; \mathrm{e}=0.17)$ and pasture stream $\left(\mathrm{H}^{\prime}=0.52\right.$; $\mathrm{D}=0.35 ; \mathrm{e}=0.14$ ).

The temporal analysis of abundance $(\mathrm{F}=$ $1.62 ; \mathrm{P}>0.05)$ and evenness $(\mathrm{F}=0.99 ; \mathrm{P}>$ 0.05 ) did not show any differences among the streams for either period (Fig. 1A, 1D). The species richness of the forested stream in the 

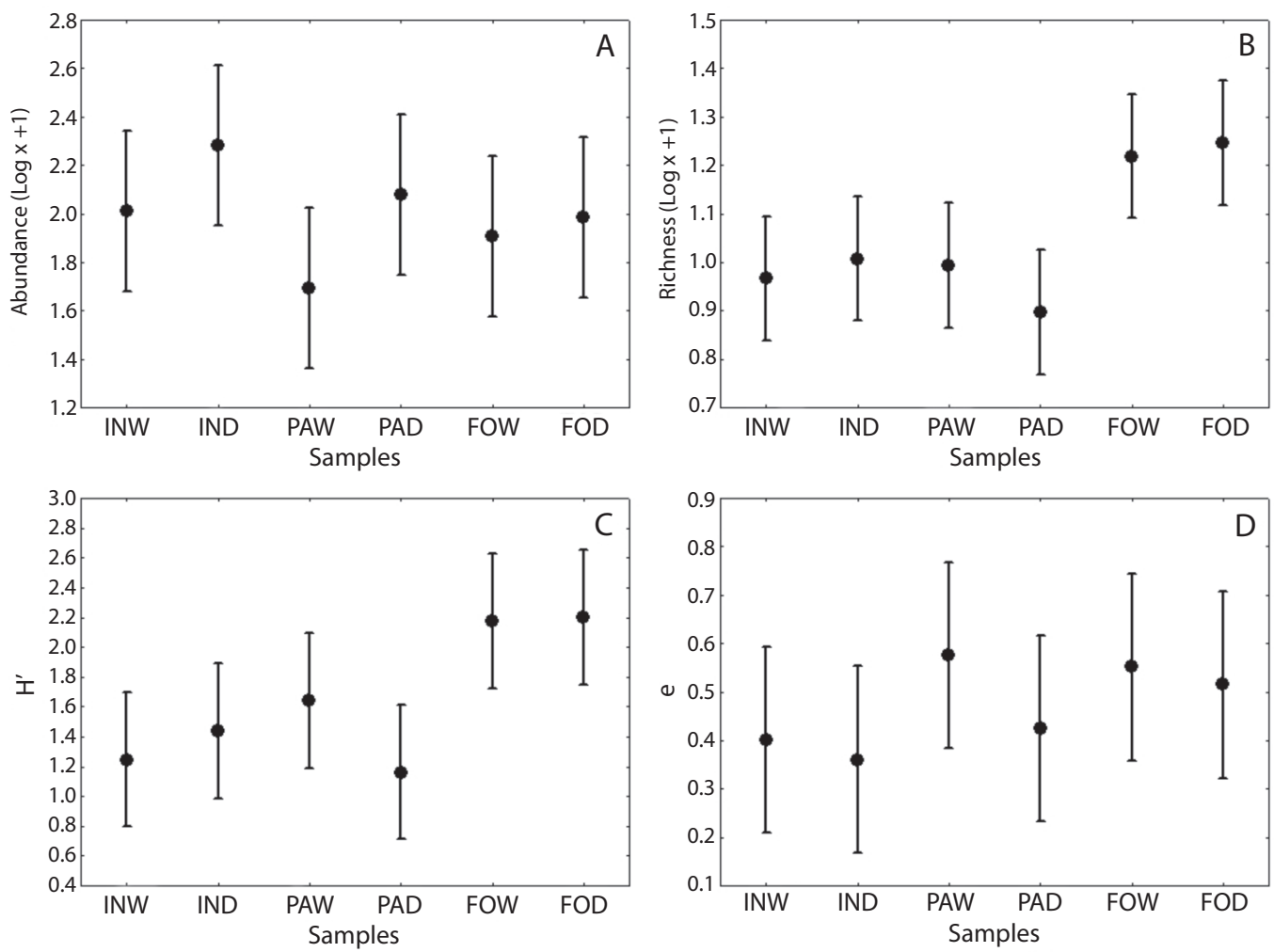

Fig. 1. Species abundance (A), richness (B), diversity (C) and evenness (D) in streams in the Machado River Basin, RO, during the dry and wet seasons. H' = Shannon-Wiener index. e = Pielou's evenness index. INW = intermediate stream/wet, $\mathrm{IND}=$ intermediate stream/dry, PAW $=$ pasture stream/wet, PAD $=$ pasture stream/dry, FOW $=$ Forested stream/wet and $\mathrm{FOD}=$ Forested stream/dry.

wet season $(\mathrm{F}=4.01, \mathrm{P}<0.05)$ and the dry season $(F=4.74, P<0.05)$ was higher than the species richness of the pasture stream during the dry season (Fig. 1B). The diversity of the forested stream in the wet season $(\mathrm{F}=3.05, \mathrm{P}$ $<0.05)$ and dry season $(\mathrm{F}=3.75, \mathrm{P}<0.05)$ was higher than the diversity of the pasture stream during the dry season (Fig. 1C). The forested and pasture streams did not show any significant differences in the parameters analyzed related to the intermediate stream.

The NMDS analysis of the samples based on species abundance showed that intermediate and pasture streams were separated from forested stream from the test mean of the scores of axis 1 (Kruskal-Wallis, $\mathrm{H}=10,1 ; \mathrm{P}<0.05$ ), which was retained for interpretation (Stress $=$ 0.09) (Fig. 2).
The comparison between fish species composition among stream groups, environmental variables and spatial distances explained together $28 \%$ of the variation $\left(R_{a d j}^{2}=0.27 ; \mathrm{F}\right.$ $=2.27 ; \mathrm{P}=0.001)$. Assemblage composition was significantly influenced by environmental variables accounted for $15 \%\left(R_{a d j}^{2}=0.15\right.$; $\mathrm{F}=1.83 ; \mathrm{P}=0.001)$, but not spatial predictors $\left(R_{a d j}^{2}=0 ; \mathrm{F}=0.73 ; \mathrm{P}=0.75\right)$. The $\mathrm{pRDA}$ indicated that ten variables were redundant, and thus these variables were excluded from the environmental data set. The forward selection procedure showed depth, water velocity, pteridophytes and grasses were the environmental variables that accounted for significant $(\mathrm{P}<0.05)$ portions of the total variance in fish species composition. The pRDA with these four environmental variables produced 


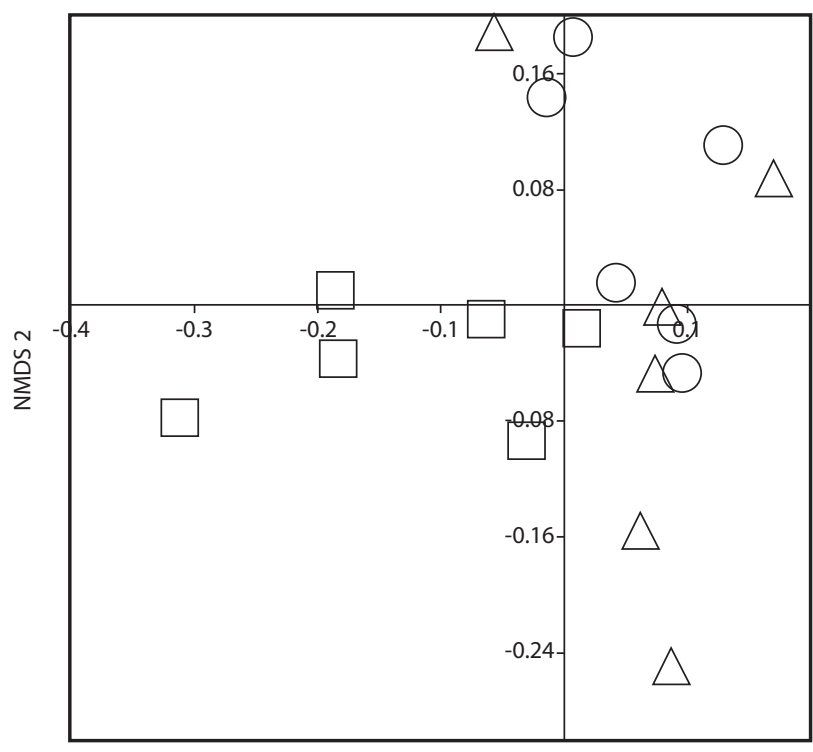

NMDS 1

Fig. 2. Projection of the first two axes of non-metric multidimensional scaling based on the abundance of species in each stream. $\square=$ forested stream, $\circ=$ intermediate stream and $\Delta=$ pasture stream.

an ordination in which all canonical axes were significant (Monte Carlo test; $\mathrm{P}<0.05$ ).

The first axis of pRDA separated the forested and intermediate stream with predominance of Knodus heteresthes, Crenicichla lepidota and Rineloricaria phoxocephala from pasture stream with predominance of Creagrutus anary and Imparfinis stictonotus (Fig. 3A). The most important abiotic variables for species composition were depth $(\mathrm{F}=2.83 ; \mathrm{P}=0.009)$, water velocity $(\mathrm{F}=2.25 ; \mathrm{P}=0.024)$, pteridophytes $(\mathrm{F}=2.02 ; \mathrm{P}=0.040)$, associated with $K$. heteresthes, $C$. lepidota and $R$. phoxocephala, and grasses $(\mathrm{F}=3.50 ; \mathrm{P}=0.002)$, associated with C. anary and I. stictonotus (Fig. 3B).

\section{DISCUSSION}

Our variance tests, NMDS and pRDA seems to support the importance of forest to improve environmental complexity and species diversity/composition corroborating with previous studies (i.e. Galuch, 2007; Teresa \& Casatii, 2010; Cruz et al., 2013; Santos,
Ferreira, \& Esteves, 2015; Casatti et al., 2015), confirming the initial hypothesis of this study in other regions and ecosystems.

The greatest richness, diversity and evenness values were observed in the forested stream. According to Mendonça (2002) and Naiman, Décamps and Mcclain (2005), the presence of riparian forests along all of the streams were responsible for the internal heterogeneity of the aquatic habitats, interception of sediments, fertilizers and pesticides that would otherwise enter the streams through surface or subterranean drainage. The riparian forests also exchanged organic matter between the terrestrial and aquatic ecosystems (Casatti et al., 2012), as a result of which the latter supported a greater diversity of species. A study with streams in the Adolfo Ducke Reserve in Manaus, found that the composition of the fish community was influenced by different types of substrate, especially trunks and litter banks (Mendonça, 2002), corroborating the results found for forested stream. The presence of large amount of submerged litter derived from leaves that fell from the riparian forest 

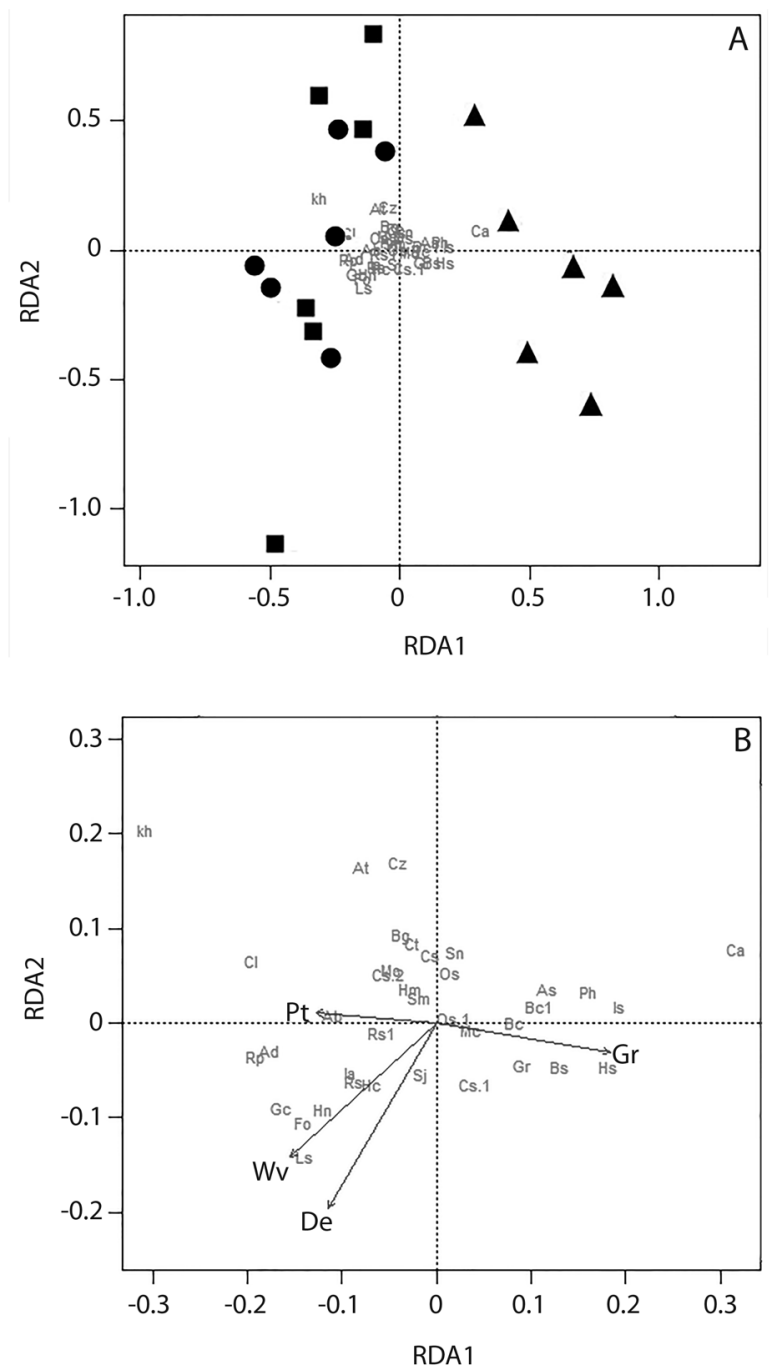

Fig. 3. Ordination of the Partial Redundancy Analysis (pRDA) on fish species composition (see abbreviations on Appendice 1) with sites ( $\boldsymbol{\square}=$ forested stream, $\bullet=$ intermediate stream and $\boldsymbol{\Delta}=$ pasture stream) (A) and abiotic variables relationships (arrows) (B). De $=$ Depth, $\mathrm{Wv}=$ Water velocity, $\mathrm{Pt}=$ Pteridophytes and $\mathrm{Gr}=$ Grasses.

resulted in greater number of microhabitats, which ensured greater fish species richness and diversity (Ferreira \& Marinelli, 2001). Even so, studies on the effects of riparian vegetation on aquatic communities have stressed the importance of local influence, because riparian buffers help the preservation of mesohabitats and found for forested stream in our study (Lorion \& Kennedy 2009; Casatti et al. 2012; Casatti et al. 2015; Santos et al. 2015).
In contrast, the removal of riparian forests changes the trophic relationships between organisms (Pusey \& Arthington, 2003) and affects the structure and composition of aquatic communities (Teresa \& Casatti, 2010). The amount of grass on the stream banks is the main predictor of functional redundancy, which indicates that despite being more numerous and diverse, the groups of species living in this condition perform similar functions 
in the ecosystem (Casatti et al., 2015). This vegetation comes from adjacent pastures in areas of limited shade from the riparian zone, and it is a good indicator of low habitat integrity (Casatti et al., 2009) and habitat homogenization (Zeni \& Casatti, 2014; Casatti et al., 2015). The occurrence of grass, as pasture stream, at the border and in the instream habitat, can provide additional microhabitats that favor the colonization, reproduction, and feeding of aquatic insects, playing a similar role to that of aquatic macrophytes, which increase macroinvertebrate abundance in streams (Casatti et al., 2015). High macroinvertebrate availability can in turn favor the persistence of fish populations of the opportunistic feeding. Among the submerged roots of grass, large amounts of sediment can be trapped with detritus that (Casatti et al., 2015), together with high respiration rates, may reduce dissolved oxygen (Bunn, Davies, \& Kellaway, 1997). In this type of environment, midge larvae are abundant and represent, along with detritus, the most consumed resources by local fish (Zeni \& Casatti, 2014). Among the species able to live in such conditions, we can cite Creagrutus anary and Imparfinis stictonotus. The species $C$. anary (Characidae), which has the highest species abundance in the pasture stream, swims in mid-waters, and most of them are small-sized (Buckup, 1999) with high feeding plasticity and a wide variety of dietary strategies (Casatti et al., 2001). Many species of Characidae are opportunistic as the use of food resources in environments heavily modified by human activity (Melo, Machado, \& Pinto-Silva, 2004; Ceneviva-Bastos \& Casatti, 2007). The incidence of I. stictonotus can be related to feeding tactics (autochthonous invertivore) and the psammophilous characteristics (sand-dwelling) found for some species of the genus (Carvalho, Zuanon, \& Sazima, 2008). Sandy bottoms are often found in Amazonian streams and harbor specialized sand-dwelling fish assemblages composed mostly of catfishes (Carvalho et al., 2008).

The forested stream in the wet and dry seasons had higher species richness and diversity than the pasture stream during the dry season, and no differences were observed for this parameter between the forested and pasture streams in relation to the intermediate stream. Comparisons made by Santos et al. (2015), in streams located in area of native forest (comprised dense ombrophilous forests, lowland vegetation, dense woody vegetation on both banks, with buffer widths of 12-18 m), secondary forest (comprised semi-deciduous and secondary dense ombrophilous vegetation, were located within sugarcane properties showing clear signs of deforestation with a relatively open understory and 6-12 $\mathrm{m}$ of riparian buffer zones) and sugarcane (riparian vegetation consisted primarily of Brachiaria type grasses, severe erosion with the presence of gullies), suggested that this component had significant effects on some aspects of the fish assemblages, such as species composition and trophic structure. Although, richness, diversity, biomass and total density were not influenced by riparian condition in Santos et al. (2005) study, these parameters of the assemblages were influenced mainly by the dry and rainy periods (seasonality).

Seasonal flooding in small streams of the Amazon forest are less predictable, with hydrological changes more related to the incidence of local rainfall (flash system) than the regular and predictable monomodal pulse of the great rivers (smooth system; Welcomme \& Halls, 2004). In small streams, local rainfall events entail an almost immediate response in increased water flow (Tomasella et al., 2008). Thus, the connection to the lateral region of the stream can act as an important refuge for fish during the period of high water, providing shelter regarding the sudden increase in discharge of streams during heavy rain events and disturbances (e.g. reduced availability of invertebrates and increased energy expenditure for maintenance position) (Piccolo, Hughes, \& Bryant, 2008). In addition, the marginal region flooded potentially serves as an important habitat for feeding and reproduction of many species (Espírito-Santo, 2015). 
Our results from the pRDA were similar to those of Barros (2008), in studies in streams of the Madeira-Purus basins, who observed that the community structure was significantly affected by depth, flow, woody angiosperms and the presence of bare bank/grasses. An increase in stream dimensions provided greater environmental heterogeneity and availability of habitats, thus increasing the species abundance and richness (Vannote, Minshall, Cummins, Sedell, \& Cushing, 1980). The presence of forests in the forested and intermediate stream probably provided a higher availability of microhabitats for species associated with trunks (Rineloricaria phoxocephala), backwater areas (Crenicichla lepidota) (Mendonça, 2002) and for species that feed on allochthonous resources (Knodus heteresthes) (Nogueira \& Costa, 2014). In the pasture stream, the presence of grasses generates environmental conditions that favored the occurrence of tolerant species (e.g., S. notomelas, $C$. anary and $B$. caudomaculatus). This indicated that changes in the fish community followed the sensitive modifications occurring in the vegetation cover of the streams, the presence or absence of trees, in each margin, in the same stream.

Our results indicated that the stream fish fauna responded to the modification of the riparian vegetation through a change in its species composition and ecological parameters of assemblages. The streams with preserved riparian vegetation represented refuges for fish fauna from the taxonomic and functional point of view. With the loss of sensitive and specialized species richness in degraded riparian vegetation and in stream habitat, it was presumed that biotic homogenization occurred, which may reduce the species diversity and ecosystem services.

\section{ACKNOWLEDGMENTS}

We are grateful to Instituto Chico Mendes de Conservação da Biodiversidade - ICMBio for Collection permits (no. 311560-1/2011) and Laboratório de Ictiologia e Pesca da Universidade Federal de Rondônia and in particular
Willan Ohara and João Filho for their help with identification of the taxonomic material.

\section{RESUMEN}

Influencia de la estructura del hábitat en el ensamble de comunidades de peces en ríos de la cuenca amazónica Machado. Igarapés son ríos amazónicos extremadamente susceptibles a los impactos ambientales. Debido al impacto de los cambios en el uso de las zonas riparias en los ensambles de peces, es importante describir y entender las relaciones entre los ensambles de peces y los factores ambientales, especialmente en áreas poco conocidas. Se estudió la composición taxonómica y los atributos del ensamble de peces en ríos bajo diferentes condiciones de conservación de la zona riparia: bosque, zona intermedia y pastos. Los muestreos se realizaron cada dos meses entre Octubre 2011 y Septiembre 2012, en tres ríos de primer orden en la cuenca del río Machado, Rondonia. Los peces fueron recolectados con redes de cerco y de profundidad ( $2 \mathrm{~mm}$ ) a lo largo de todo el tramo. Se registró un total de 2141 ejemplares pertenecientes a 59 especies, 17 familias y 5 órdenes. A diferencia de la zona intermedia y pasto, el bosque mostró una alta riqueza y baja abundancia. El área boscosa exhibió el valor más alto de diversidad y uniformidad, y baja dominancia, a diferencia de los otros sitios. La varianza particionada y el análisis de redundancia parcial (pRDA) indicaron que la composición del ensamble fue significativamente explicado por las variables ambientales como: profundidad, velocidad del agua, pteridofitas y pastos, pero no por predictores espaciales. El análisis de escalamiento multidimensional no métrico (EMNM) mostró que los ríos de sitios intermedios y pastos estaban separados de los ríos del bosque. Llegamos a la conclusión de que las variables ambientales de los ríos y los atributos del ensamble de peces se ven influenciados por los diferentes niveles de conservación y cobertura del suelo. En vista de la influencia de los procesos regionales en el ensamble de peces locales, el uso del suelo a escala de cuenca es importante, especialmente para explicar la alta riqueza y diversidad que se encuentra en el los ríos del área boscosa.

Palabras clave: complejidad, conservación, riqueza, comunidad de peces.

\section{REFERENCES}

Barbour, M. T., Gerritsen, J., Snyder, B. D., \& Stribling, J. B. (1999). Rapid bioassessment protocols for use in streams and wadeable rivers. Washington: USEPA.

Barletta, M., Jaureguizar, A. J., Baigun, C., Fontoura, N. F., Agostinho, A. A., Almeida-Val, V. M. F., Val, A. L., Torres, R. A., Jimenes-Segura, L. F., Giarrizzo, T., Fabre', N. N., Batista, V. S., Lasso, C., Taphorn, D. C., Costa, M. F., Chaves, P. T., 
Vieira, J. P., \& Correa, M. F. M. (2010). Fish and aquatic habitat conservation in South America: a continental overview with emphasis on neotropical systems. Journal of Fish Biology, 76(9), 2118-2176. doi/10.1111/j.1095-8649.2010.02684.x

Barros, D. F. (2008). Estrutura de comunidades de peixes de igarapés na região do interflúvio Madeira-Purus. Pará: UFPA.

Borcard, D., Gillet, F., \& Legendre, P. (2011). Numerical Ecology with R. New York: Springer.

Borcard, D., \& Legendre, P. (2002). Partialling out the spatial component of ecological variation. Ecology, $73,1045-1055$.

Buckup, P. A. (1999). Sistemática e biogeografia de peixes de riachos - Ecologia de Peixes de Riachos. Série Oecologia Brasiliensis, 6, 91-138.

Bunn, S. E., Davies, P. M., \& Kellaway, D. M. (1997). Contributions of sugar cane and invasive pasture grass to the aquatic food web of a tropical lowland stream. Marine \& Freshwater Research, 48, 173-179.

Carvalho, L. N., Zuanon, J., \& Sazima, I. (2008). Natural history of Amazon fishes. In P. S. O. Claro \& V. Rico-Gray (Eds.), Tropical biology and conservation management (pp. 1-32). Oxford: Eolss Publishers.

Casatti, L., Ferreira, C. P., \& Carvalho, F. R. (2009). Grass-dominated stream sites exhibit low fish species diversity and dominance by guppies: an assessment of two tropical pasture river basins. Hydrobiologia, 632, 273-283. doi:10.1007/s10750-009-9849-y.

Casatti, L., Langeani, F., \& Castro, R. M. C. (2001). Peixes de riacho do Parque Estadual Morro do Diabo, bacia do alto rio Paraná, SP. Biota Neotropica, 1, 1-15.

Casatti, L., Pérez-Mayorga, M. A., Carvalho, F. R., Brejão, G. L., \& Costa, I. D. (2013). The stream fish fauna from the rio Machado basin, Rondônia State, Brazil. Check List, 9, 1496-1504.

Casatti, L., Teresa, F. B., Gonçalves-Souza, T., Bessa, E., Manzotti, A. R., Gonçalves, C. S., \& Zeni, J. O. (2012). From forests to cattail: How does the riparian zone influence stream fish? Neotropical Ichthyology, $10,205-214$.

Casatti, L., Teresa, F. B., Zeni, J. O., Ribeiro, M. D., Brejão, G. L., \& Ceneviva-Bastos, M. (2015). More of the same: high functional redundancy in stream fish assemblages from tropical agroecosystems. Environmental Management, 55, 1300-1314. doi: 10.1007/ s00267-015-0461-9.

Ceneviva-Bastos, M., \& Casatti, L. (2007). Oportunismo alimentar de Knodus moenkhausii (Teleostei, Characidae): uma espécies abundante em riachos do noroeste do Estado de São Paulo, Brasil. Iheringia, Série Zoologia, 97, 7-15.
Clarke, K. R., \& Warwick, R. M. (1994). Similarity-based testing for community pattern: the two-way layout with no replication. Marine Biology, 118, 167-176.

Colwell, R. K. (2013). EstimateS: statistical estimation of species richness and shared species from samples, Version 9. Available from: $<$ http://viceroy.eeb.uconn. edu/estimates>

Costa, I. D. (2014). Estrutura das assembleias de peixes de igarapés de terra firme da bacia do rio Machado/RO. Rio de Janeiro: UERJ.

Cruz, B. B., Miranda, L. E., \& Cetra, M. (2013). Links between riparian landcover, instream environment and fish assemblages in headwater streams of south $\square$ eastern Brazil. Ecology of Freshwater Fish, 22, 607-616. doi: 10.1111/eff.12065.

Dembkowski, D. J., \& Miranda, L. E. (2012). Hierarchy in factors affecting fish biodiversity in floodplain lakes of the Mississippi Alluvial Valley. Environmental Biology of Fishes, 93, 357-368. doi: 10.1007\%2Fs10641-011-9923-y.

Dray, S. D., Legendre, P., \& Peres-Neto, P. R. (2006). Spatial modelling: a comprehensive framework for principal coordinate analysis of neighbour matrices (PCNM). Ecological Modelling, 196, 483-493.

Espírito-Santo, H. M. V. (2015). Cuidado onde pisa: poças temporárias têm importante papel na ecologia de peixes em igarapés de terra firme na Amazônia. Manaus, INPA.

Fernandes, L. C., \& Guimarães, S. C. P. (2002). Atlas geoambiental de Rondônia. Porto Velho, Brasil: SEDAM.

Ferreira, A., Cyrino, J. E. P., Duarte-Neto, P. J., \& Martinelli, L. A. (2012). Permeability of riparian forest strips in agricultural, small subtropical watersheds in south-eastern Brazil. Marine \& Freshwater Research, $63,1272-1282$

Ferreira, K., \& Marinelli, C. E. (2001). Composição, riqueza e abundância da ictiofauna de um igarapé de terra firme da Amazônia Central, AM. Curso de Campo Ecologia da Floresta Amazônica, 157, 87-89.

Fitzgerald, D. G., Kott, E., Lanno, R. P., \& Dixon, D. G. (1998). A quarter century of change in the fish communities of three small streams modified by anthropogenic activities. Journal of Aquatic Stress and Recovery, 6, 111-127.

Foley, J. A., Asner, G. P., Costa, M. H., Coe, M. T., DeFries, R., Gibbs, H. K., Howard, E. A., Olson, S., Patz, J., Ramankutty, N., \& Snyder, P. (2007). Amazonia revealed: forest degradation and loss of ecosystem goods and services in the Amazon Basin. Frontiers in Ecology and the Environment, 5, 25-32.

Galuch, A. V. (2007). Adaptação de um Índice de Integridade Biótica para igarapés da Amazônia 
Central, com base em atributos ecológicos da comunidade de peixes. (Dissertação de Mestrado). INPA/UFAM, Manaus.

Google Earth (2016). KML Gallery: Explore the Earth on Google [On Line] Retirado de http://earth.google. com/gallery/index.html

Gorman, O. T., \& Karr, J. R. (1978). Habitat structure and stream fish communities. Ecology, 59, 507-515.

Hammer, Ø., Harper, D. A. T., \& Ryan, P. D. (2001). PAST: Paleontological Statistics Software Package for Education and Data Analysis. Palaeontologia Electronica, 4, 9.

Hartmann, D. L., Klein Tank, A. M. G., Rusticucci, M., Alexander, L. V., Brönnimann, S., Charabi, Y., Dentener, F. J., Dlugokencky, E. J., Easterling, D. R., Kaplan, A., Soden, B. J., Thorne, P. W., Wild, M., \& Zhai, P. M. (2013). Observations: Atmosphere and Surface. In T. F. Stocker., D. Qin, G. K. Plattner, M. Tignor, S. K. Allen, J. Boschung, A. Nauels, Y. Xia, V. Bex, \& P. M. Midgley (Eds.), Climate Change 2013: The Physical Science Basis. Contribution of Working Group I to the Fifth Assessment Report of the Intergovernmental Panel on Climate Change (pp. 1-33). Cambridge: Cambridge University Press.

Hoeinghaus, D. J., Winemiller, K. O., \& Birnbaum, J. S. (2007). Local and regional determinants of stream fish assemblage structure: inferences based on taxonomic vs. functional groups. Journal of Biogeography, 34, 324-338. doi: 10.1111/j.1365-2699.2006.01587.x

Krusche, A. V., Ballester, M. V. R., Victoria, R. L., Bernardes, R. C., Leite, N. K., Hanada, L., Victoria, D. C., Toledo, A. M., Ometto, J. P., Moreira, M. Z., Gomes, B. M., Bolson, B. A., Neto, S. G., Bonelli, N., Deegan, L., Neill, C., Thomas, S., Aufdenkampe, A. K., \& Richey, J. E. (2005). Efeitos das mudanças do uso da terra na biogeoquímica dos corpos d'água da bacia do rio Ji-Paraná, Rondônia. Acta Amazonica, 35, 197-205.

Laudon, H., Kuglerová, L., Sponseller, R. A., Futter, M., Nordin, A., Bishop, K., Lundmark, T., Egnell, G., \& Agren, A. M. (2016). The role of biogeochemical hotspots, landscape heterogeneity, and hydrological connectivity for minimizing forestry effects on water quality. Ambio, 45, 152-162.

Levêque, C., Oberdorff, T., Paugy, D., Stiassny, M. L. J., \& Tedesco, P. A. (2008). Global diversity of fish (Pisces) in freshwater. Hydrobiologia, 595, 545-567.

Lorion, C. M., \& Kennedy, B. P. (2009). Riparian forest buffers mitigate the effects of deforestation on fish assemblages in tropical headwater streams. Ecological Applications, 19, 468-479.

Ludwig, J. A., \& Reynolds, J. F. (1988). Statistical Ecology. A primer on methods and computing. New York: John Wiley \& Sons.
Melo, C. E., Machado, F. A., \& Pinto-Silva, V. (2004). Feeding habits of fish from a stream in the savanna of Central Brazil, Araguai Basin. Neotropical Ichthyology, 2, 37-44.

Mendonça, F. P. (2002). Ictiofauna de igarapés de terra firme: estrutura das comunidades de duas bacias hidrográficas Reserva Florestal Adolfo Ducke, Amazonia Central. Manaus: INPA.

Mendonça, F. P., Magnusson, W. E., \& Zuanon, J. (2005). Relationships between habitat characteristics and fish assemblages in small streams of Central Amazonia. Copeia, 4, 751-764.

Miserendino, M. L., Casaux, R., Archangelsky, M., Di Prinzio, C. Y., Brand, C., \& Kutschker, A. M. (2011). Assessing land-use effects on water quality, in-stream habitat, riparian ecosystems and biodiversity in Patagonian northwest streams. Science of The Total Environmental, 409, 612-624.doi: 10.1016/j. scitotenv.2010.10.034.

Naiman, R. J., Décamps, H., \& Mcclain, M. E. (2005). Riparia: ecology, conservation, and management of streamside communities. Burlington: Elsevier Academic Press.

Nogueira, W. V., \& Costa, I. D. (2014). Aspectos da alimentação de Knodus heteresthes (Characiformes, Characidae) no igarapé do Nove, bacia do rio Machado, Rondônia, Brasil. Biotemas, 27, 97-108. doi: $10.5007 / 2175-7925.2014 \mathrm{v} 27 \mathrm{n} 3 \mathrm{p} 97$

Peres-Neto, P. R., Legendre, P., Dray, S., \& Borcard, D. (2006). Variation partitioning of species data matrices: estimation and comparison of fractions. Ecology, $87,2614-2625$.

Piccolo, J. J., Hughes, N. F., \& Bryant, M. D. (2008). Water velocity influences prey detection and capture by driftfeeding juvenile coho salmon (Oncorhynchus kisutch) and steelhead (Oncorhynchus mykiss irideus). Canadian Journal of Fisheries and Aquatic Sciences, 65, 266-275.

Pusey, B. J., \& Arthington, A. A. (2003) Importance of the riparian zone to the conservation and management of freshwater fish: a review. Marine \& Freshwater Research, 54, 1-16.

Queiroz, L. J., Torrente-Vilara, G., Ohara, W. M., Pires, T. H. S., Zuanon, J., \& Doria, C. R. C. (2013). Peixes do Rio Madeira. São Paulo: Dialeto latin american documentary.

R Development core team. (2009). R: a language and environment for statistical computing, Version 2.9.1. Available from: $<$ http://www.R-project.org $>$

Reis, R. E., Kullander, S. O., \& Ferraris, J. R. (2003). Check list of the freshwater fishes of South and Central America. Porto Alegre: Edipucrs. 
Rosenvald, R., Järvekülg, R., \& Lõhmus, A. (2014). Fish assemblages in forest drainage ditches: Degraded small streams or novel habitats? Limnologica - Ecology and Management of Inland Waters, 46, 37-44. doi:10.1016/j.limno.2013.12.004

Roth, N. E., Allan, J. D., \& Ericson, D. L. (1996). Landscape influence on stream biotic integrity assessed at multiple spatial scales. Landscape Ecology, 11, 141-156.

Santos, F. B., Ferreira, F. C., \& Esteves, K. E. (2015). Assessing the importance of the riparian zone for stream fish communities in a sugarcane dominated landscape (Piracicaba River Basin, Southeast Brazil). Environmental Biology of Fishes, 98, 1895-1912. doi: 10.1007/s10641-015-0406-4

Tedesco, P. A., Oberdorff, T., Lasso, C. A., Zapata, M., \& Hugueny, B. (2005). Evidence of history in explaining diversity patterns in tropical riverine fish. Journal of Biogeography, 32, 1899-1907.

Ter Braak, C. J. F., \& Smilauer, P. (1998). Canoco reference manual and user's guide to Canoco for windows: software for canonical community ordination, version 4. Ithaca: Microcomputer Power.

Teresa, F. B., \& Casatti, L. (2010). Importância da vegetação ripária em região intensamente desmatada no sudeste do Brasil: um estudo com peixes de riacho. Pan-American Journal of Aquatic Sciences, $5,444-453$

Tomasella, J., Hodnett, M. G., Cuartas, L. A., Nobre, A. D., Waterloo, M. J., \& Oliveira, S. M. (2008). The water balance of an Amazonian micro-catchment: the effect of interannual variability of rainfall on hydrological behaviour. Hydrological Processes, 22, 2133-2147.

Vannote, R. L., Minshall, G. W., Cummins, K. W., Sedell, J. R., \& Cushing, C. E. (1980). The river continuum concept. Canadian Journal of Fisheries and Aquatic Sciences, 37, 130-137.

Walker, I. (1995). Amazonian streams and small rivers. In J. G. Tundisi, C. E. M. Bicudo, \& T. MatsumuraTundisi (Eds.), Limnology in Brazil (pp. 167-193). São Paulo: Sociedade Brasileira de Limnologia/ Academia Brasileira de Ciências.

Welcomme, R. \& Halls, A. (2004). Dependence of tropical fisheries on flow. In R. Welcomme, \& R. Petr (Eds.), Proceedings of the Second International Symposium on the Management of Large Rivers for Fisheries (pp. 267-283). Bangkok: FAO Regional Office for Asia and the Pacific.

Zeni, J. O., \& Casatti, L. (2014). The influence of habitat homogenization on the trophic structure of fish fauna in tropical streams. Hydrobiologia, 726, 259-270. Doi: i:10.1007/s10750-013-1772-6 
